\title{
ANALISIS RASIO KEUANGAN DALAM MEMPREDIKSI PERUBAHAN LABA PERUSAHAAN MANUFAKTUR YANG TERDAFTAR DI BURSA EFEK INDONESIA
}

\author{
Febriyanto $^{1}$, Riza Setiawan Gusma ${ }^{2}$ \\ Universitas Muhammadiyah Metro ${ }^{12}$ \\ Email : Febriyanto0223027901@gmail.com
}

Received :

03-23-2021

Received in Revised

Format :

03-26-2021

Accepted :

03-28-2021

Available Online :

03-31-2021

\section{ABSTRAC}

Rapid technological developments make the capital market create various opportunities or alternatives for investors. On the other hand, companies seeking funds must compete in obtaining funding from investors. One way for companies to get funding is by issuing and selling company shares to investors on the stock exchange. As with the problem formulation, the purpose of writing this thesis is to provide empirical evidence about the effect of changes in Current Ratio (CR), Debt To Equity Ratio (DER), Gross Profit Margin Ratio (GPM), and Total Asset Turnover Ratio (TAT) in predicting profit changes in automotive sub-sector manufacturing companies for the next one year. The target population of this study is all manufacturing companies listed on the Indonesian stock exchange. The automotive sub-sector and reported in 2018 to June 2020, with purposive sampling technique, the research sample was obtained as many as 12 automotive companies. The data analysis tool used in this research is multiple regression analysis test, classical assumption test, and hypothesis test. Based on the results of research and discussion, the following conclusions can be made about the positive and significant effect of the Current Ratio on changes in earnings, there is no significant effect on Debt To Equity, Gross Profit Margin, Total Asset Turnover on changes in earnings. And together it cannot have a significant effect on changes in earnings.

Key word: Current Ratio, Debt To Equity, Gross Profit Margin, Total Asset Turnover, Income Change 


\section{PENDAHULUAN}

Suatu perusahaan dapat dilihat melalui laporan keuangan yang menyajikan informasi akuntansi secara teratur dalam periode tertentu. Namun para investor akan mencari dan menanamkan investasinya pada perusahaan yang memberikan retrun yang tinggi. Laporan keuagan merupakan hasil dari proses akuntansi yang digunakan untuk berkomunikasi antara data keuangan atau aktivitas suatu perusahaan dengan pihak-pihak yang berkepentingan dengan data atau aktivitas perusahaan tersebut (Munawir, 2014:2). Laba biasa dipakai sebagai ukuran dari prestasi yang dicapai perusahaan. Untuk mengetahui laba perusahaan maka para investor harus melihat laporan keuangan yang di terbitkan suatu perusahaan, karena tujuan laporan keuangan disajikan adalah untuk menyediakan informasi yang berguna bagi calon investor dan krediturnya. Laporan keuangan perusahaan dapat memperoleh informasi posisi keuangan, kinerja, dan aliran kas perusahaan termasuk laba yang didapat suatu perusahaan.Investor juga harus mengetahui laba yang didapat oleh perusahaan meningkat atau menurun pada suatu periode, maka untuk mengetahuinya investor dapat melihat persentase perubahan laba. Perubahan laba adalah perubahan persentase laba yang diperoleh perusahaan, perubahan laba meningkat mengisyaratkan bahwa perusahaan mempunyai keuangan yang baik.Perusahaan dengan laba yang sedang tumbuhmencerminkan perusahaan itu adalah perusahaan bersekala besar yang memiliki aktiva, tingkat produksi, dan tingkat penjualan yang tinggi sehingga menghasilkan profit perusahaan yang besar setiap tahunnya.

Dalam memprediksi perubahan laba pada periode yang ditentukan maka peneliti menggunakan rasio keuangan untuk mengetahui apakah terdapat pengaruh rasio keuangan terhadap perubahan laba. Rasio keuangandapat dipahami sebagai hasil yang diperoleh antara satu jumlah dengan jumlah yanglain. Rasio keuangan dapat digunakan untuk menjelaskan atau memberi gambarankepada penganalisa tentang baik buruknya keadaan atau kondisi keuangan suatuperusahaan (Munawir, 2010:44). Dalam penelitian ini,rasio-rasio keuangan sebagai salah satu informasi dalam laporan keuangan yangdigunakan untuk memprediksi labaperusahaan dimasa mendatang.Rasio keuangan yang dipakai dalam memprediksi perubahan laba padapenelitian ini adalah: rasio likuiditas di wakili current ratio,rasio solvabilitas diwakili debt to equity ratio, rasio profitabilitas di wakili grossprofit margin, dan rasioaktivitas di wakili total asset turnoverrasio. Jadi dalam penelitian ini dimaksutkan melakukan uji lebih lanjut temuan empires tentang rasio keuangan, khususnya mengenai kegunaan dalam memprediksi laba yang akan datang.

Berikut penelitian sebelumnya mengenai rasio keuangan mengenai perubahan laba. Justina (2015) dalam penelitiannya menyimpulkan variabel Curren Ratio $(C R)$, dan net profit margin mempunyai pengaruh yang positif terhadap perubahan laba, sedangkan variabel Debt to Equity Ratio (DER), dan Total Asset Turnover (TATO) tidak pengaruh signifikan terhadap perubahan laba. Sedangkan Demawan (2011) memiliki kesimpulan bahwa rasio yang dapat digunakan sebagai prediksi perubahan laba adalah $C R$, $O P M$, NIS, dan $S C L$ kemudian variabel GPM, ROE, ITO, dan TATO tidak dapat menjadi prediksi perubahan laba. Penelitian ini memliki tujuan untuk mengetahui apakah current ratio, debt to equityratio, gross profit margin, dan total asset turnover secara individu dan bersama-samaberpengaruh dalam memprediksi perubahan laba pada perusahaan manufaktur sub sektor Otomotif di Bursa efek Indonesia.

\section{METODE PENELITIAN}

Untuk mengetahui lebih jelas suatu masalah yang diteliti, maka disini akan diberikan gambaran kerangka pemikiran desain penelitian secara skematis sebagai berikut : 


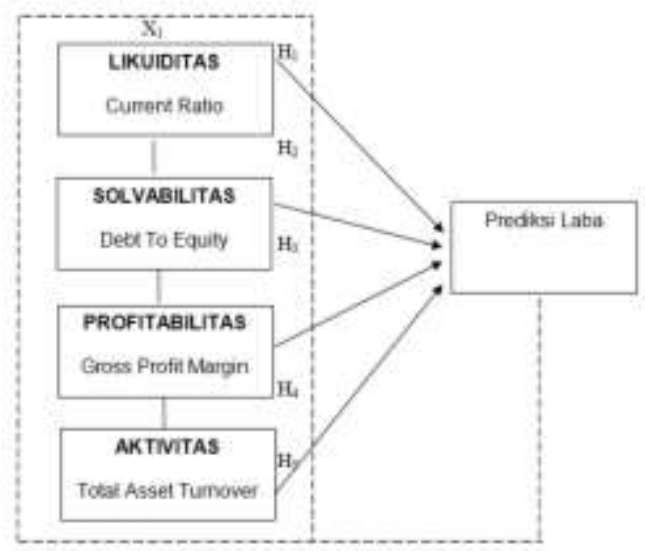

Gambar 1. Kerangka Pemikiran

Jenis Penelitian yang digunakan ini bersifat kuantitatif karena data penelitian berupa angka-angka dan data yang telah dikumpulkan. Dalam penelitian ini objek penelitiaan adalahdata laporan keuangan perusahaan sub sektor otomotif di Bursa Efek indonesia. Perusahaan yang termasuk sub sektor otomotif adalah Astra International Tbk, Astra Otoparts Tbk, Garuda Metalindo Tbk, Indo Kordsa Tbk, Goodyear Indonesia Tbk, Gajah Tunggal Tbk, Indomobil Sukses International Tbk, Indospring Tbk, Multi Prima Sejahtera Tbk, Multistrada Arah Sarana Tbk, Prima Alloy Steel Universal Tbk, dan Selamat Sempurna Tbk.

Populasi dan sampel menurut Sugiyono (2013:115-116), ialah "Wilayah generalisasi yang terdiri atas objek/subjek yang mempunyai kualitas dan karakteristik tertentu yang ditetapkan oleh peneliti untuk dipelajari dan kemudian ditarik kesimpulan. Dan sampel ialah bagian dari jumlah dan karakteristik yang dimiliki oleh populasi tersebut." Maka populasi penelitian ini ialah seluruh perusahaan manufaktur sub otomotif yang ada di bursa efek indonesia pada tahun 2018-2020. Sampel yang didapat penelitian ini adalah 12 perusahaan dibursa efek indonesia. Teknik pengambilan sampel penelitian ini berupa sampling purvosive merupakan teknik penentuan sampel dengan pertimbangan tertentu. Kriteria yang dijadikan pertimbangan dalam pengambilan sampel ialah :
1. Perusahaan manufaktur sub sektor otomotif yang ada di bursa efek Indonesia.

2. Seluruh perusahaan otomotif yang ada di Bursa Efek Indonesia yang mengeluarkan laporan keuangan setiap tahunan.

3. Perusahaan otomotif yang sudah dilisting ipo di Bursa Efek Indonesia.

Dalam penelitian ini metode pengumpulan data yang digunakan adalah Metode Dokumentasi, yaitu :

a. Studi Kepustakaan

Peneliti mendapatkan data degan mengunduh laporan keuangan dengan mengakses situs idx.co.id, lalu melihat dan meminjam literatur di perpusatakaan untuk mengumpulkan data dan mengakses internet untuk mendapatkan jurnal dan skripsi yang dapat membantu dalam penelitian ini.

Dalam penelitian ini memiliki variabel bebas, (X) yaitu rasio keuangan current ratio sebagai (X1), debt to equity ratio sebagai (X2), gross profit margin sebagai (X3), dan total asset turnover sebagai (X4), yang masing-masing variabel bebas adalah perwakilan dari tiap-tiap rasio keuangan yang ada, dan Variabel terikat penelitian ini adalah hasil prediksi perubahan laba perusahaan Sub Sektor Otomotif sebagai (Y).

Metode yang digunakan untuk menganalisis data adalah metode kualitatif dengan alat analisis regresi berganda. Analisis ini menggunakan perubahan laba sebagai varibel dependen dan perubahan rasio keuangan sebagai variabel independen dengan menggunakan persamaan regresi berganda yaitu :

$\mathrm{Y}=\mathrm{a}+\mathrm{b}_{1} \mathrm{X}_{1}-\mathrm{b}_{2} \mathrm{X}_{2}+\mathrm{b}_{3} \mathrm{X}_{3}+\mathrm{b}_{4} \mathrm{X}_{4}-\mathrm{b}_{5} \mathrm{X}_{5}+\mathrm{e}$

\begin{tabular}{|l|l|}
\hline Dimana : & \\
$\mathrm{Y}$ & Pertumbuhan laba \\
$\mathrm{a}$ & Konstanta \\
$\mathrm{b}$ & Koefisisenregresi \\
\hline
\end{tabular}




\begin{tabular}{|l|l|}
\hline $\mathrm{X}_{1}$ & $\begin{array}{l}\text { Perubahan Current } \\
\text { Ratio (CR) }\end{array}$ \\
\hline $\mathrm{X}_{2}$ & $\begin{array}{l}\text { Perubahan Leverage } \\
\text { Ratio (LR) }\end{array}$ \\
\hline $\mathrm{X}_{3}$ & $\begin{array}{l}\text { Perubahan Inventory } \\
\text { Turnover (IT) }\end{array}$ \\
\hline $\mathrm{X}_{4}$ & $\begin{array}{l}\text { Perubahan Operating } \\
\text { Profit Margin (OPM) }\end{array}$ \\
\hline $\begin{array}{l}\mathrm{X}_{5} \\
\mathrm{e}\end{array}$ & $\begin{array}{l}\text { Perubahan Price } \\
\text { Earning Ratio (PER) } \\
\text { Koefisien Error }\end{array}$ \\
\hline
\end{tabular}

\section{HASIL PENELITIAN DAN PEMBAHASAAN}

1. Koefisien regresi variabel current ratio $\left(\beta_{1}\right)$ sebesar 1,089 dengan $t_{\text {hitung }} 1,942$ pada $=0,05$ diperoleh $\mathrm{t}_{\text {tabel }} 1.895$. Karena nilai $t_{\text {hitung }}>t_{\text {tabel }}$, maka koefisien data signifikan. Dari temuan ini dapat disimpulkan bahwa $\mathrm{H}_{1}$ yang menyatakan current ratio $\left(\mathrm{X}_{1}\right)$ berpengaruh terhadap perubahan laba(Y) diterima. Artinya ada pengaruh current ratio terhadapperubahan laba.

2. Koefisien regresi variabel debt to equity ratio $\left(\beta_{2}\right)$ sebesar -925 dengan thitung (2,061) pada $=0,05$ diperoleh ttabel 1.895. karena nilai thitung <ttabel, maka koefisien data tidak signifikan. Dari temuan ini dapat disimpulkan bahwa $\mathrm{H} 2$ yang menyatakan debt to equity ratio $\left(\mathrm{X}_{2}\right)$ berpengaruh terhadap perubahan laba(Y) ditolak. Artinya tidak ada pengaruh debt to equity ratio terhadap perubahan laba.

3. Koefisien regresi variabel gross profit margin ( $\beta 3)$ sebesar (-672) dengan thitung $(-536)$ pada $=0,05$ diperoleh ttabel 1.895. karena nilai thitung < ttabel, maka koefisien data tidak signifikan. Dari temuan ini dapat disimpulkan bahwa $\mathrm{H} 3$ yang menyatakan gross profit margin $\left(\mathrm{X}_{3}\right)$ berpengaruh terhadap perubahan laba (Y) ditolak. Artinya tidak ada pengaruh gross profit margin terhadapperubahan laba.

4. Koefisien regresi variabel total asset turnover ( $\beta 4)$ sebesar (-461)dengan thitung $(-550)$ pada $=0,05$ diperoleh ttabel 1.669. karena nilai thitung < ttabel, maka koefisien data tidak signifikan. Dari temuan ini dapat disimpulkan bahwa $\mathrm{H} 4$ yang menyatakan total asset turnover $\left(\mathrm{X}_{4}\right)$ berpengaruh terhadap perubahan laba (Y) ditolak. Artinya tidak ada pengaruh total asset turnover terhadapperubahan laba.

5. Nilai konstan bernilai 4,420 dengan nilai positif. Hal ini menunjukan bahwa apabila variabelcurrent ratio, debt to equity ratio, gross profit margin, dan total asset turnover sama dengan nol, maka perubahan laba sebesar 4,420.

\section{KESIMPULAN DAN SARAN}

\section{A. Kesimpulan}

Penelitian ini bertujuan untuk mengetahui pengaruh hubungan antara rasio keuangan dalm memprediksi laba pada perusahaan manufaktur pada sektor otomotif. Berdasarkan pada data yang sudah dikumpulkan dan pengujian yang telah dilakukan maka hasil yang didapat ialah sebagai berikut:

1. Current Ratio memiliki pengaruh signifikan dan positif terhadap perubahan laba perusahaan manufaktur pada sektor otomotif.

2. Debt to Equity Ratio tidak memiliki pengaruh signifikan dan negatif terhadap perubahan laba perusahaan manufaktur pada sektor otomotif.

3. Gross Profit Margin tidak memiliki pengaruh signifikan dan negatif terhadap perubahan laba perusahaan manufaktur pada sektor otomotif.

4. Total Asset Turnover tidak memiliki pengaruh signifikan dan negatif terhadap perubahan laba perusahaan manufaktur pada sektor otomotif.

5. Rasio keuangan current ratio, debt to equity ratio, gross profit margin dan total asset turnover tidak dapat berpengaruh signifikan dan negatif terhadap perubahan laba secara bersama-sama perusahaan manufaktur pada sektor otomotif. 


\section{B. Saran}

Adapun saran yang diberikan setelah melakukan penelitian ini antara lain:

1. Bagi investor yang akan berinvestasi di pasar modal diharapkan untuk terlebih dulu mempelajari kondisi keuangan perusahaan untuk dapat memprediksi kekuatan perusahaan yang dapat dilihat dari laporan keuangan dengan memperhatikan pengaruh perubahan-perubahan rasio keuangan terhadap perubahan laba.

2. Bagi penelitian selanjutnya diharapkan dapat menggunakan variabelvariabel bebas yang lain untuk mengetahui rasio-rasio keuangan lain yang dapat digunakan untuk memprediksi perubahan laba.

3. Penelitian ini tidak mempertimbangkan ukuran perusahaan/size effect dan memasukkan faktor-faktor ekonomi seperti inflasi, tingkat bunga, dan sebagainya, yang mungkin berpengaruh pada angka-angka akuntansi atau laporan keuangan yang digunakan sebagai data dalam penelitian ini, maka untuk penelitian selanjutnya diharapkan memasukkan unsur-unsur tersebut di atas.

\section{DAFTAR PUSTAKA}

Agustina. (2016). Analisa Faktor-Faktor Yang Mempengaruhi Perubahan Laba Dengan Ukuran Perusahaan Sebagai Variabel Moderating Pada Perusahaan Manufaktur Yang Terdaftar Di BEI. Jurnal Wira Ekonomi Mikrosil. 6 (1).

Abdul Halim. (2016). Akuntansi Sektor Publik Akuntansi Keuangan Daerah. Jakarta : Salemba Empat.

Arikunto, Suharsimi. (2010). Prosedur Penelitian Suatu Pendekatan Praktik.. Jakarta : Rineka Cipta.
Arikunto, Suharsimi. (2013). Prosedur Penelitian Suatu Pendekatan Praktik. Jakarta : Rineka Cipta.

Bringham, Eugene F. dan Joel F Houston. (2012). Dasar-dasar Manajemen Keuangan Edisi kesebelas. Jakarta : Alih Bahasa Salemba Empat.

Bambang, Riyanto. (2011). Dasar-Dasar Pembelanjaan Perusahaan. Yogyakarta

Yayasan Badan Penerbit Gadjah Mada. Chyntia Sirila Manurung \& Evelin R.R Silalahi. (2016). Analisis Rasio Keuangan Dalam Memprediksi Perubahan Laba Pada Perusahaan Manufaktur yang Terdaftar Di Bursa Efek Indonesia (BEI). JRAK-Vol. 2 No. 1. ISSN 2252-6552.

Demawan, Shigyt, dan Amir. 2011. Analisis Rasio Keuangan Untuk Memprediksi Perubahan Laba. Jurnal Media Ilmiah Ekonomi dan Bisnis. Vol 3, No. 2: juli 2011.

Dian. (2015). Analisis Pengaruh Rasio Keuangan dan Ukuran Aset Terhadap Perubahan Laba Perusahaan Manufaktur yang Terdaftar Di BEI Periode 2010-2013. Tidak Dipublikasikan. Jember : Fakultas Ekonomi dan Bisnis Universitas Jember.

Dita. (2016). Pengaruh Rasio Keuangan Terhadap Perubahan Laba Pada Perusahaan Pertambangan Logam Di BEI. Jurnal Ilmu dan Riset Manajemen, 5 (6).

Fahmi, Irham. (2012). Manajemen Investasi. Jakarta: Selemba Empat.

Ghozali, Imam. (2013). Aplikasi Analisis Multivariate Dengan Program IBM SPSS 21. Semarang : Badan Penerbit Universitas Diponegoro.

Harahap, Sofyan Syafri. (2010). Analisa Kritis atas Laporan Keuangan. Jakarta: PT Raja Gafindo Persada.

Horne, James C. Van dan Jhon M Wachowicz, Jr. (2012). Prinsip-perinsip manajemen Keuangan (Edisi 13). Jakarta: Selemba Empat. 
Ikatan Akuntansi Indonesia. (2012). Standar Akuntansi Keuangan. Jakarta : Selemba Empat.

Kasmir. (2010). Pengantar Manajemen keuangan. Jakarta : Kencana Prenada Media Group.

Kasmir. (2010). Pengantar Manajemen Keuangan Edisi Pertama. Cetakan Kedua. Jakarta: Kencana Prenada Media Group.

Munawir, S. (2010). Analisa Laporan Keuangan. Yogyakarta : Liberty.

Munawir, S. (2012). Analisis Informasi Keuangan. Yogyakarta : Liberty.

Munawir, S. (2014). Analisis Laporan Keuangan. Yogyakarta : Liberty.

Nazir, M. (2014). Metode Penelitian. Bogor : Ghalia Indonesia.

Nur Amalina dan Arifin Sabeni. (2011). Analisis Rasio Keuangan Dalam Memprediksi Perubahan Laba : ( Studi Empiris Pada Perusahaan Manufaktur Yang Terdaftar Pada Bursa Efek Indonesia Periode Tahun 2008-2011. Diponegoro Journal of Accounting. Volume 3. Nomor 1. Tahun 2014. Halaman 6.

Samryn, L.M. (2012). Akuntansi Manajemen Informasi Biaya untuk Mengendalikan Aktivitas Operasi dan Investasi. Edisi Pertama. Jakarta: Kencana Prenada Media Group.

Samryn, L.M. (2015). Pengantar Akuntansi-Metode Akuntansi untuk Elemen

Laporan Keuangan Diperkaya dengan Perspektif IFRS \& Perbankan. Edisi Pertama. Jakarta : PT Raja Grafindo Persada.

Siswandi. (2011). Aplikasi Manajemen Perusahaan: Analisis kasus dan pemecahannya edisi 3. Jakarta : Mitra Wacana Media.

Subramanyam. K. R dan John J. Wild. (2014). Analisi Laporan Keuangan. Penerjemah Dewi Y. Jakarta: Salemba Empat.

Sugiyono. (2013). Metode Penelitian Bisnis (Pendekatan Kuantitatif,
Kualitatif dan R\&D). Bandung: Alfabeta.

Sugiyono. (2011). Metode Penelitian Kuantitatif Kualitatif Dan $R \& D$. Bandung : Alfabeta.

$\underline{\text { www.idx.co.id }}$ 